\title{
Daya Hambat Ekstrak Kulit Semangka (Citrullus lanatus) terhadap Pertumbuhan Candida albicans
}

\section{(Inhibitory Extract of Watermelon (Citrullus lanatus) Rind on Candida albicans Growth)}

\author{
Nindya Nur Maghfiroh, Ayu Mashartini Prihanti, Purwanto \\ Fakultas Kedokteran Gigi Universitas Jember \\ Jln. Kalimantan 37, Jember 68121 \\ e-mail korespondensi: nindyanurmaghfiroh@gmail.com
}

\begin{abstract}
Candida albicans is normal flora found in the oral mucosa in healthy individuals but has opportunistic pathogenic properties. The change in the oral cavity's environmental conditions can cause $C$. albicans to turn into a pathogen and cause oral candidiasis. Antifungal drugs that are common used for the treatment of oral candidiasis are topical nystatin preparations. Nystatin is an antifungal drug from the polyene group produced by Streptomyces noursei, which is thought to be very effective in treating diseases caused by C. albicans with a success rate $79.6-87.5 \%$. The previous study showed that watermelon peel extract contains active compounds of alkaloids, flavonoids, tannins, and saponins. The active compound is known to have antifungal activity. The study aimed to determine the ability of watermelon peel extract to inhibit the growth of $C$. albicans. The type of research conducted is experimental laboratories using the post-test only control group design. The observations in this study about the inhibitory power of watermelon rind extract (Citrullus lanatus) on the growth of $C$. albicans showed that there were inhibitory zones of watermelon skin extract on the growth of $C$. albicans.
\end{abstract}

Keywords: Candida albicans, oral candidiasis, extract of watermelon rind.

\begin{abstract}
Abstrak
Candida albicans merupakan salah satu flora normal yang terdapat pada mukosa rongga mulut pada individu yang sehat, namun memiliki sifat patogen oportunistik. Adanya perubahan kondisi lingkungan di dalam rongga mulut dapat menyebabkan $C$. albicans akan berubah menjadi patogen dan menyebabkan terjadinya kandidiasis oral. Obat antijamur yang sering digunakan untuk pengobatan kandidiasis oral adalah nistatin sediaan topikal. Nistatin merupakan obat antijamur dari golongan poliene yang diproduksi oleh Streptomyces noursei yang diduga sangat efektif dalam mengobati penyakit yang disebabkan oleh C. albicans dengan tingkat keberhasilan 79,6 - 87,5\%. Penelitian sebelumnya melaporkankan bahwa ekstrak kulit buah semangka diketahui mengandung senyawa aktif alkaloid, flavanoid, tanin dan saponin. Senyawa aktif tersebut dikenal memiliki aktifitas sebagai antijamur. Tujuan penelitian ini adalah mengetahui kemampuan ekstrak kulit buah semangka dalam menghambat pertumbuhan $C$. albicans. Jenis penelitian yang dilakukan merupakan penelitian experimental laboratories dengan menggunakan rancangan the post-test only control group design. Hasil pengamatan pada penelitian ini tentang daya hambat ekstrak kulit semangka (Citrullus lanatus) terhadap pertumbuhan $C$. albicans menunjukkan terdapat zona hambat ekstrak kulit semangka terhadap pertumbuhan $C$. albicans.
\end{abstract}

Kata kunci: Candida albicans, kandidiasis oral, ekstrak kulit semangka. 


\section{Pendahuluan}

Candida albicans (C. albicans) merupakan salah satu flora normal yang terdapat pada mukosa rongga mulut pada individu yang sehat namun memiliki sifat patogen oportunistik. Pada rongga mulut, $C$. albicans menetap di dorsum lidah bagian posterior [1]. Adanya perubahan kondisi lingkungan di dalam rongga mulut akibat kebersihan rongga mulut yang buruk, menurunnya jumlah saliva [2], serta gangguan imunitas, xerostomia, dan penggunaan obatobatan (kortikosteroid, atau antibiotik spektrum luas) dalam jangka panjang, pemakaian dentures serta kebiasaan merokok dapat menyebabkan $C$. albicans akan berubah menjadi patogen dan menyebabkan terjadinya kandidiasis oral [1].

Kandidiasis oral yang sering muncul yaitu berupa lesi pseudomembran dan lesi eritematosus. Pseudomembran memiliki tanda klinis berupa lesi bercak atau plak putih yang terdapat di lidah, palatum, dan bukal, kemudian jika dikerok akan terlepas, meninggalkan permukaan mukosa merah dan dapat disertai perdarahan ringan. Sedangkan untuk jenis kandidiasis eritematosus secara klinis ditandai oleh adanya area merah biasanya pada dorsum lidah dan palatum dan jarang terjadi pada mukosa bukal [1]. Insidensi kandidiasis oral di Indonesia terjadi peningkatan hingga $85-95 \%$ [3].

Berbagai jenis obat telah banyak digunakan sebagai antijamur akibat infeksi $C$. albicans, antara lain adalah golongan poliene, golongan imidazole, golongan triazole, golongan echinocandins [4]. Obat antijamur yang sering digunakan untuk pengobatan kandidiasis oral adalah nistatin sediaan topikal. Nistatin merupakan obat antijamur dari golongan poliene yang diproduksi oleh Streptomyces noursei. Nistatin diduga sangat efektif dalam mengobati penyakit yang disebabkan oleh $C$. albicans dengan tingkat keberhasilan 79,6 - 87,5\% [5]. Nistatin memiliki aktivitas antijamur yaitu dengan cara mengikat ergosterol dalam membran sel jamur. Hasil dari ikatan ini menyebabkan terbentuknya pori pada membran sel jamur. Pori tersebut menyebabkan keluarnya kalium serta komponen sel yang lain pada sel jamur dan menyebabkan kematian dari sel jamur [6].

Penggunaan nistatin secara topikal yaitu sebanyak empat kali sehari dalam dua minggu. Penggunaan dengan cara tersebut dapat menyebabkan mual, muntah, dan diare [7].
Adanya efek samping tersebut, diperlukan obat alternatif untuk kandidiasis oral yang memiliki sedikit efek samping. Kini mulai berkembang pesat pengobatan alternatif yaitu pengobatan menggunakan tanaman yang memiliki khasiat tertentu. Tanaman berkhasiat ini dapat menimbulkan sedikit efek samping dan juga mudah didapat serta harganya juga terjangkau [8].

Buah semangka digemari masyarakat karena mudah didapat dan harganya tergolong murah. Buah semangka juga salah satu buah yang mudah ditemukan karena buah semangka tidak tumbuh musiman. Pada saat mengkonsumsi buah semangka, masyarakat hanya mengkonsumi bagian daging buah saja sedangkan pada kulit bagian dalam buah yaitu pada lapisan putih atau biasa disebut albedo, sangatlah kurang diminati masyarakat untuk dikonsumsi dan hanya dibuang menjadi limbah yang tidak dimanfaatkan. Pemanfaatan kulit bagian dalam buah semangka untuk saat ini masih tergolong kurang maksimal. Lapisan putih pada kulit buah semangka tersebut banyak mengandung zat-zat yang berguna bagi kesehatan [9]. Menurut penelitian Rahmi Muthia (2017), menunjukkan ekstrak kulit buah semangka diketahui mengandung senyawa aktif alkaloid, flavanoid, tanin dan saponin [10]. Senyawa aktif tersebut dikenal memiliki aktifitas sebagai antijamur. Pada penelitian sebelumnya, senyawa aktif tersebut terbukti dapat merusak membran sel jamur sehingga menyebabkan terhambatnya pertumbuhan C.albicans [11].

Tanaman semangka adalah salah satu tanaman yang tumbuhnya merambat. Batang tanaman semangka tergolong lunak, berambut, dan panjangnya mencapai 1,5-5 meter. Daun semangka berseling, bertangkai dan helaian daunnya lebar serta ujungnya runcing, tepian daun bergelombang dan tulang daunnya berbentuk menjari serta panjang daun sekitar 3$25 \mathrm{~cm}$ dan lebar daun 1,5-5 cm [12].

Buah semangka memiliki bentuk yang sangat bervariasi dengan diameter 15 hingga 20 $\mathrm{cm}$, lalu panjang 20 hinga $40 \mathrm{~cm}$, dan berat 4 hingga $20 \mathrm{~kg}$. Untuk bentuk buahnya secara umum dibedakan menjadi tiga, yaitu bulat, oval dan lonjong. Semangka memiliki kulit buah yang tebal, licin dan berdaging. Warna kulit luar semangka beragam, seperti hijau tua atau hijau muda bergaris putih. Daging kulit semangka berwarna putih dan disebut albedo [12].

Semangka merupakan salah satu buah yang memiliki kandungan air cukup tinggi. Buah semangka diketahui sangat bermanfaat bagi 
tubuh karena mengandung berbagai macam vitamin seperti vitamin $A$, vitamin $B$, vitamin $C$, selain itu juga mengandung karbohidrat dan juga kalium. Namun, pada bagian kulit buah semangka juga banyak mengandung zat-zat yang bermanfaat bagi tubuh yang jarang orang ketahui.

Berdasarkan penelitian Rahmi Muthia (2017), setelah melakukan identifikasi kimia menunjukkan ekstrak kulit buah semangka diketahui mengandung senyawa alkaloid, flavanoid, tanin dan saponin.

Senyawa flavanoid dikenal sebagai antijamur. Senyawa flavonoid juga merupakan kelompok senyawa fenol yang menghambat mikroba dengan cara meracuni protoplasma, merusak dan menembus dinding sel, serta mengendapkan protein sel mikroba. Sebagai antijamur, gugus hidroksil yang terdapat pada senyawa flavonoid menyebabkan perubahan komponen organik dan transport nutrisi yang akhirnya akan mengakibatkan sel jamur menjadi lisis [13]. Komponen fenol pada flavonoid juga mendenaturasi enzim yang bertanggung jawab terhadap germinasi spora atau berpengaruh terhadap asam amino yang terlibat dalam proses germinasi.

Tanin adalah senyawa yang juga dikenal sebagai antijamur. Mekanisme antijamur yang dimiliki tanin adalah karena kemampuannya menghambat sintesis khitin yang digunakan untuk pembentukan dinding sel pada jamur. Selain itu, tanin mampu merusak membran sel sehingga pertumbuhan jamur terhambat [14]. Tanin juga bersifat lipofilik sehingga mudah terikat pada dinding sel dan mengakibatkan kerusakan dinding sel pada jamur.

Saponin dapat menyebabkan sel mikroba lisis dengan mengganggu stabilitas membran sel. Saponin bertindak sebagai surfaktan yang akan menurunkan tegangan permukaan membran sterol dari dinding sel $C$. albicans, sehingga menyebabkan gangguan permeabilitas membran yang dapat mengakibatkan pemasukan bahan atau zat-zat yang diperlukan dapat terganggu, dan menyebabkan sel membengkak lalu pecah [11].

Kandidiasis adalah infeksi jamur yang terjadi karena adanya pembiakan jamur secara berlebihan, dimana dalam kondisi normal muncul dalam jumlah yang kecil. Kandidiasis oral adalah suatu infeksi oportunistik yang disebabkan oleh $C$. albicans dan sering dijumpai di bagian mukosa oral. Selain itu, juga sering dijumpai pada mukosa bukal, lipatan mukosa bukal, orofaring dan lidah [15]. C. albicans adalah salah satu komponen dari mikroflora normal rongga mulut dan sekitar $30 \%$ sampai $50 \%$ orang mempunyai mikroorganisme ini dan jumlahnya akan meningkat seiring dengan bertambahnya usia [11].

C. albicans merupakan mikroorganisme komensal atau flora normal dalam rongga mulut [1] dan dapat berubah menjadi patogen bila terdapat faktor resiko seperti menurunnya imunitas, gangguan endokrin, terapi antibiotik dalam jangka waktu lama, perokok dan kemoterapi. Perubahan C. albicans menjadi patogen menyebabkan penyakit yang disebut kandidiasis oral.

Tujuan pada penelitian ini adalah mengetahui kemampuan ekstrak kulit buah semangka dalam menghambat pertumbuhan $C$. albicans.

\section{Metode Penelitian}

Jenis penelitian yang dilakukan merupakan penelitian experimental laboratories dengan menggunakan rancangan the post test only control group design. Penelitian dilakukan di Laboratorium Mikrobiologi Fakultas Kedokteran Gigi Universitas Jember, pembuatan ekstrak kulit buah semangka dilakukan di Laboratorium Biologi Farmasi Fakultas Farmasi Universitas Jember dan identifikasi tanaman semangka (Citrullus lanatus) dilakukan di Laboratorium Tanaman Jurusan Produksi Pertanian Politeknik Negeri Jember. Penelitian dilakukan pada bulan Agustus 2018 sampai September 2018.

Variabel bebas dari penelitian ini adalah ekstrak kulit semangka (Citrullus lanatus) dengan konsentrasi $100 \%$. Variabel terikat dari penelitian ini adalah zona hambat ekstrak kulit semangka (Citrullus lanatus) terhadap pertumbuhan $C$. albicans.

Alat ukur adalah alat yang digunakan untuk mengetahui besaran suatu benda. Alat ukur yang akan digunakan pada penelitian kali ini adalah jangka sorong dengan ketelitian 0,01 $\mathrm{mm}$. Alat ini nantinya akan digunakan untuk mengukur besar zona hambat yang terbentuk pada media SDA yang telah diinokulasi $C$. albicans.

Besar sampel minimal berdasarkan perhitungan rumus Federer adalah 8,5 dan dapat dibulatkan menjadi 9 sampel pada masing-masing kelompok. Sehingga jumlah keseluruhan sampel penelitian yang digunakan sebanyak 27 sampel. Kelompok sampel dibagi menjadi 3, yaitu kelompok ekstrak kulit 
semangka dengan konsentrasi $100 \%$, kelompok kontrol positif (nistatin), dan kelompok kontrol negatif (akuades steril).

\section{Hasil Penelitian}

Data yang diperoleh dari hasil perhitungan rata-rata diameter zona hambat ditabulasi kemudian dilakukan analisis data secara statistik dari hasil data yang didapatkan. Rata-rata diameter zona hambat terhadap $C$. albicans dapat dilihat pada tabel dibawah:

Tabel 1. Rata-rata diameter zona hambat terhadap pertumbuhan C. albicans

\begin{tabular}{ccc}
\hline Perlakuan & $\begin{array}{c}\text { Rata-rata } \\
\text { diameter zona } \\
\text { hambat }\end{array}$ & SD \\
\hline Ekstrak $100 \%$ & $7,78 \mathrm{~mm}$ & 0,97 \\
Kontrol (+) & $15,11 \mathrm{~mm}$ & 0,78 \\
Kontrol (-) & $0,00 \mathrm{~mm}$ & 0,00 \\
\hline
\end{tabular}

Keterangan:

Eks $100 \%=$ Ekstrak kulit buah semangka konsentrasi $100 \%$

$\mathrm{K}_{+}=$kontrol positif yaitu nistatin

$\mathrm{K}-=$ Kontrol negatif yaitu akuades steril

$\mathrm{SD}=$ Standar deviasi

Tabel 1 menunjukkan rata-rata diameter zona hambat terbesar yaitu $\mathrm{K}+$ atau nistatin sebesar 15,11 mm, kemudian diikuti ekstrak kulit semangka konsentrasi $100 \%$ yaitu $7,78 \mathrm{~mm}$. Untuk K- yaitu akuades steril, tidak memiliki kemampuan menghambat pertumbuhan $C$. albicans, sehingga hasil yang diperoleh adalah $0,00 \mathrm{~mm}$.

Data hasil penelitian yang telah dirata-rata, selanjutnya dilakukan uji normalitas Kolmogorov-Smirnov.

Tabel 2. Hasil uji normalitas menggunakan uji Kolmogorov-Smirnov

\begin{tabular}{lclc}
\hline $\begin{array}{l}\text { Kelompok } \\
\text { Perlakuan }\end{array}$ & $\mathrm{n}$ & $\begin{array}{l}\text { Kolmogorov- } \\
\text { Smirnov }\end{array}$ & Signifikansi \\
\hline Eks 100\% & 9 & 0,771 & 0,591 \\
K (+) & 9 & 0,670 & 0,761 \\
K (-) & 9 & 0,000 & 0,000 \\
\hline
\end{tabular}

Tabel 2 menunjukkan hasil dari uji Kolmogorov-Smirnov. Pada ekstrak kulit buah semangka dan nistatin didapatkan signifikasi lebih besar dari 0,05. Pada ekstrak kulit buah semangka memiliki signifikansi 0,591 dan pada kontrol positif (+) yaitu nistatin diperoleh signifikansi sebesar 0,761. Namun pada kontrol negatif yaitu akuades steril diperoleh signifikansi 0,00 . Menurut uji Kolmogorov-Smirnov, data tidak terdistribusi normal, karena pada kontrol negatif yaitu akuades steril signifikansinya lebih kecil dari 0,05 yaitu 0,00. Selanjutnya dilakukan uji homogenitas menggunakan uji Levene's. Uji Levene's ini bertujuan untuk mengetahui varian data homogen atau tidak.

Tabel 3. Hasil uji homogenitas menggunakan uji Levene's

\begin{tabular}{lllll}
\hline $\begin{array}{c}\text { Levene's } \\
\text { Statistic }\end{array}$ & df1 & df2 & Sig \\
\hline 7,636 & 2 & 24 & 0,003 & \\
\hline
\end{tabular}

Tabel 3 menunjukkan hasil uji homogenitas menggunakan uji Levene's didapatkan nilai signifikasi lebih kecil dari 0,05 yaitu 0,003 sehingga data yang didapatkan tidak homogen. Selanjutnya dilakukan uji non parametrik yaitu uji Kruskal-Wallis. Uji KruskalWallis ini bertujuan untuk mengetahui ada atau tidaknya perbedaan pada seluruh kelompok sampel.

Tabel 4. Hasil uji non parametrik Kruskal-Wallis

\begin{tabular}{|c|c|c|c|c|c|}
\hline & Perlakuan & $n$ & $\begin{array}{l}\text { Mean } \\
\text { Rank }\end{array}$ & df & $p$ \\
\hline \multirow{3}{*}{$\begin{array}{l}\text { Diameter } \\
\text { zona } \\
\text { hambat }\end{array}$} & Eks 100 & 9 & 14,00 & 2 & 0,000 \\
\hline & $\begin{array}{l}\text { Akuades } \\
\text { steril }\end{array}$ & 9 & 5,00 & & \\
\hline & $\begin{array}{l}\text { Nistatin } \\
\text { Total }\end{array}$ & $\begin{array}{l}9 \\
27\end{array}$ & 23,00 & & \\
\hline
\end{tabular}

Tabel 4 menunjukkan hasil uji non parametrik Kruskal-Wallis, didapatkan nilai signifikasi lebih kecil dari 0,05 yaitu 0,000, artinya data yang didapatkan terdapat perbedaan pada seluruh kelompok penelitian. Selanjutnya dilakukan uji Mann-Whitney untuk mengetahui kelompok perlakuan mana yang berbeda bermakna.

Tabel 5. Hasil uji non parametrik Mann-Whitney

\begin{tabular}{llll}
\hline $\begin{array}{l}\text { Kelompok } \\
\text { Perlakuan }\end{array}$ & $\begin{array}{l}\text { Eks } \\
100\end{array}$ & $\mathrm{~K}(+)$ & $\mathrm{K}(-)$ \\
\hline Eks 100 & $(-)$ & 0,000 & 0,000 \\
\hline $\mathrm{K}(+)$ & 0,000 & $(-)$ & 0,000 \\
\hline $\mathrm{K}(-)$ & 0,000 & 0,000 & $(-)$ \\
\hline
\end{tabular}


Tabel 5 menunjukkan bahwa signifikansi pada ekstrak kulit buah semangka $100 \%$, kontrol positif yaitu nistatin dan kontrol negatif yaitu akuades steril lebih kecil dari 0,05. Hal ini membuktikan bahwa data terdapat perbedaan.

\section{Pembahasan}

Aktifitas dari antijamur dapat diketahui berdasarkan 2 metode yaitu metode difusi dan metode dilusi. Penelitian ini menggunakan metode difusi sumuran. Alasan pada penelitian ini menggunakan metode difusi sumuran dikarenakan metode tersebut memiliki beberapa keunggulan seperti memberikan akurasi yang tinggi, dan juga memudahkan senyawa aktif pada ekstrak untuk berdifusi ke media tanpa perantara [16].

Terdapat teori tentang kriteria respon zona hambat menurut David dan Stout (1971) yang mengelompokkan respon zona hambat menjadi 5 kriteria. Pertama, yaitu tidak ada zona hambat (zona hambat $0 \mathrm{~mm}$ ), lemah (zona hambat kurang dari $5 \mathrm{~mm}$ ), sedang (zona hambat 5-10 mm), kuat (zona hambat 11-20 $\mathrm{mm}$ ) dan sangat kuat (zona hambat lebih dari 20 $\mathrm{mm}$ ). Menurut teori dari David dan Stout tersebut, maka dapat disimpulkan bahwa ekstrak kulit buah semangka (Citrullus lanatus) mempunyai efek antijamur kategori sedang dikarenakan zona hambat yang terbentuk pada ekstrak kulit semangka sebesar 7,78 $\mathrm{mm}$ dan masuk pada kriteria sedang.

Hasil penelitian menunjukkan bahwa ekstrak kulit buah semangka memiliki efek antijamur dan diduga kuat sebagai antijamur karena berpotensi menghambat pertumbuhan $C$. albicans. Zona hambat yang terbentuk disekitar sumuran menunjukkan bahwa senyawa aktif pada ekstrak kulit buah semangka bekerja dengan baik dalam menghambat pertumbuhan jamur. Senyawa aktif tersebut diantaranya adalah senyawa alkaloid, flavonoid, tanin, dan saponin.

Senyawa aktif seperti senyawa alkaloid, flavonoid, tanin dan saponin memiliki mekanisme antijamur hampir mirip. Senyawa alkaloid dapat menyebabkan pori pada sel jamur karena berikatan dengan ergosterol. Hal tersebut menyebabkan kebocoran membran dan kematian pada sel jamur. Senyawa flavonoid menyebabkan terjadinya perubahan komponen organik pada sel jamur sehingga dapat mengganggu transpor nutrisi sel dan sel jamur lisis [13]. Tanin dapat menghambat sintesis zat khitin. Sehingga menyebabkan pembentukan dinding sel jamur tidak sempurna dan mudah terjadi kerusakan sel, sehingga sel jamur menjadi lisis [14]. Saponin sebagai antijamur dapat menurunkan tegangan permukaan membran dinding sel jamur sehingga terjadi gangguan permeabilitas membran, lalu sel membengkak dan akhirnya sel jamur akan pecah [11].

Beberapa senyawa aktif yang terdapat pada ekstrak kulit buah semangka (Citrullus lanatus) yaitu senyawa alkaloid, flavonoid, tanin dan saponin, terdapat 2 senyawa aktif yang lebih menoonjol dari senyawa lainnya. Senyawa tersebut adalah tanin dan alkaloid. Jika dilihat pada tinjauan pustaka, senyawa alkaloid memiliki mekanisme yang mirip dengan kontrol positif yaitu nistatin [17].

Penelitian ini menggunakan akuades steril sebagai kontrol negatif dan nistatin sebagai kontrol positif. Alasan penelitian ini menggunakan akuades steril sebagai kontrol negatif yaitu sebagai kontrol. Berdasarkan hasil penelitian diketahui kontrol negatif yaitu akuades steril tidak terbentuk zona hambat di sekitar sumuran $(0,00 \mathrm{~mm})$. Hal tersebut membuktikan bahwa ekstrak kulit buah semangka (Citrullus lanatus) memiliki aktifitas antijamur meskipun hanya masuk kriteria sedang. Nistatin digunakan sebagai kontrol positif karena nistatin merupakan salah satu obat antijamur yang sangat efektif dalam mengobati penyakit yang disebabkan oleh $C$. albicans dengan tingkat keberhasilan 79,6 - 87,5\% [5]. Hal tersebut didukung dengan hasil penelitian yang membuktikan bahwa diameter zona hambat rata-rata pada nistatin adalah $15,11 \mathrm{~mm}$. Obat antijamur nistatin memiliki mekanisme kerja dengan cara mengikat ergosterol yang merupakan komponen utama dinding sel jamur. Hal tersebut menyebabkan terbentuknya pori pada membran sel jamur yang nantinya dapat menyebabkan kebocoran kalium dan kematian sel jamur [18].

Hasil penelitian menunjukkan ekstrak kulit buah semangka (Citrullus lanatus) memiliki daya hambat terhadap pertumbuhan $C$. albicans. Hal ini dikarenakan pada ekstrak kulit buah semangka terkandung zat-zat aktif diantaranya adalah senyawa alkaloid, flavonoid, tanin, dan saponin. Pada penelitian ini, ekstrak kulit semangka (Citrullus lanatus) yang digunakan hanyalah konsentrasi $100 \%$. Dan diameter zona hambat yang terbentuk termasuk kriteria sedang. Alasan zona hambat yang terbentuk masuk kriteria sedang, kemungkinan disebabkan karena pada konsentrasi 100\% 
konsistensi bahan ekstrak kental sehingga zat aktif yang terdapat dalam konsentrasi tersebut kurang efektif berdifusi ke dalam sumuran. Maka dari itu diperlukan penelitian lanjutan untuk meneliti dengan berbagai macam konsentrasi untuk mendapatkan hasil yang akurat.

\section{Simpulan dan Saran}

Berdasarkan hasil penelitian dapat ditarik kesimpulan bahwa ekstrak kulit semangka (Citrullus lanatus) dapat menghambat pertumbuhan $C$. albicans.

Perlu penelitian lebih lanjut mengenai daya hambat daya hambat ekstrak kulit buah semangka (Citrullus lanatus) terhadap $C$. albicans dengan berbagai konsentrasi, daya hambat ekstrak kulit buah semangka (Citrullus lanatus) terhadap mikroflora lain pada rongga mulut, penelitian dengan metode lain untuk membandingkan keefektifannya dalam menghambat pertumbuhan $C$. albicans.

\section{Daftar Pustaka}

[1] Nur'aeny N, Hidayat W, Dewi TS, Herawati E, dan IS. Wahyuni. 2017. Profil oral candidiasis di bagian ilmu penyakit mulut rshs bandung periode 2010-2014. 3 (1).

[2] Lestari PE. 2010. Peran faktor virulensi pada patogenesis infeksi Candida albicans. Stomatognatic (J.K.G Unej). 7 (2): 113-117.

[3] Maharani S, dan Santoso O. 2012. Pengaruh pemberian ekstrak siwak (Salvadora persica) pada berbagai konsentrasi terhadap pertumbuhan Candida albicans. Jurnal PDGI. (2): 61-64.

[4] Sari DNR, dan Susilo DK. 2017. Perbandingan kemampuan ekstrak kulit pisang agung semeru dan pisang mas kirana varietas lumajang dalam menghambat pertumbuhan Candida Albicans. Jurnal Florea. 4(2).

[5] Lyu X, Chen Z, Zhi MY, dan Hua H. 2016. Efficacy of nystatin for the treatment of oral candidiasis: A Systematic Review and Meta-Analysis. Drug Des Devel Ther.10: 1161-1171.

[6] Fauziah GF. 2014. Perbedaan potensi antijamur ekstrak etanolik kulit manggis (Garcinia Mangostana L.) dengan nistatin terhadap C. Albicans in vitro. Skripsi.
Yogyakarta: Fakultas Kedokteran Gigi Universitas Gadjah Mada.

[7] Akpan A, dan Morgan R. 2016. Oral candidiasis. Postgrad Med J: 78:455-459.

[8] Candrasari A, Romas MA, Hasbi M, dan Astuti OR. 2012. Uji daya anti mikroba ekstrak daun sirih merah (Piper crocatum Ruiz dan pav.) terhadap pertumbuhan Staphylococcus aureus ATCC 6538, Eschericia coli ATCC 11229 dan Candida albicans ATCC 10231 secara in vitro. Biomedika 4(1): 9-16

[9] Ismayanti, Bahri S, dan Nurhaeni. 2013. Kajian kadar fenolat dan aktivitas antiosidan jus kulit buah semangka (Citrullus lanatus). Online Jurnal of Natural Science. 2(3): 100-110.

[10] Muthia R, Amalia A, Rizaldi MP, dan Amadia. 2017. Uji aktivitas in vivo ekstrak etanol kulit buah semangka (Citrullus lanatus L.) sebagai diuretik dengan pembanding furosemid. Jurnal Borneo Journal of Pharmascientech. 01 (01).

[11] Kurniawati A, Mashartini A, dan Fauzla IF. 2016. Perbedaan khasiat anti jamur antara ekstrak etanol daun Kersen (Muntingia calabura L.) dengan nistatin terhadap pertumbuhan Candida albicans.

[12] Sobir SFD. 2010. Budidaya Semangka Panen 60 Hari. Jakarta: Penebar Swadaya.

[13] Abad MJ, Ansuategui M. and Bermejo P. 2007. Active antifungal substances from natural sources. Arkivoc. 2: 116-145.

[14] Watson RR, dan Preedy VR. 2007. Bioactive Foods in Promoting Health: Probiotics and Prebiotics. USA: Academy Press.

[15] Hakim L, dan Ramadhian R. 2015. Kandidiasis oral. 4 (9).

[16] Asmardi A, Roza RM, Fitmawati. 2014. Aktivitas Antibakteri Ekstrak Daun Cyclea Barbata (I.) Miers. terhadap Bakteri Escherichia coli dan Salmonella typhi. JOM FMIPA. 1(2): 1-9.

[17] Johnson JT, Iwang EU, Hemen JT, Odey MO, Efiong EE, and Eteng OE. 2012. Evaluation of anti-nutrient contents of watermelon Citrullus lanatus.Scholars Research Library.3: 5145-5150.

[18] Kicklighter SD. 2002. Antifungal Agents and Fungal Prophylaxis in The Neonate. Neo Reviews. 3:249-54. 